\title{
Analisis Komposisi Soundtrack Epic "You See Big Girl” Karya Hiroyuki Sawano dalam Serial Animasi Attack on Titan
}

\author{
Metta Muliani \\ Program Studi Seni Musik, Fakultas Seni, Universitas Universal \\ E-mail: metta.muliani@yahoo.co.id
}

\begin{abstract}
Action-fantasy are some movie genres that has the most expansive franchises in film industry and tend to use cinematic music to correlate the atmosphere and emotions of the movie's imaginary universe. The analysis of You See Big Girl is due to its majestic cinematic music arrangement, its suitability in accompanying the battle scene, and also can be enjoyed as an independent track despite of its role in accompanying the scene. This qualitative descriptive research aims to analyze the musical composition technique by describing the epic musical element. This research contains of literature study, discography, and observation as the research methods, along with the approach of Lehman and Derrick Werlé's examine on epic music to analyze the epic element. The result shows that the You See Big Girl is one of the various epic music with the use of battle and war instrument, as well as tension built gradually from a section to the following by the use of polyrhythm, marcato accent, big crescendo, sequence, sudden silence to ends the musical phrase, ostinato, and abstract theme, to portray a majestic, vibrant, war and battle scene, and the greatness through the music.
\end{abstract}

Keywords: analysis, composition, animation, epic soundtrack, you see big girl

\begin{abstract}
Abstrak: Action-fantasy merupakan genre yang diproduksi secara lebih meluas dalam industri perfilman dan cenderung menggunakan musik cinematic yang mampu menggambarkan suasana dan emosi pada dunia imajiner dalam film tersebut. Pemilihan You See Big Girl sebagai objek penelitian dikarenakan penataan musik cinematic yang megah, kesesuaiannya mengiringi suasana pertarungan pada narasi, juga sebagai musik mandiri yang dinikmati terlepas dari perannya mengiringi adegan. Penelitian kualitatif deskriptif ini bertujuan untuk menganalisis teknik pengolahan komposisi soundtrack You See Big Girl dengan mendeskripsikan elemen musik epic di dalamnya. Metode penelitian yang digunakan adalah studi literatur, studi diskografi, dan observasi, serta pendekatan dengan teori Lehman dan Derrick Werlé untuk menganalisis elemen-elemen musik epic. Hasil penelitian menunjukkan bahwa You See Big Girl merupakan salah satu karya musik epic dengan penggunaan instrumen yang berkaitan dengan pertarungan dan peperangan, serta membangun peningkatan ketegangan dari suatu bagian ke bagian berikutnya melalui poliritmik, aksen marcato, big crescendo, sekuen, sudden silence yang mengakhiri periode kalimat, ostinato, dan abstract theme, untuk menggambarkan suasana megah, semangat, aksi pertarungan dan peperangan, serta kesan hebat melalui musiknya.
\end{abstract}

Kata Kunci: analisa, komposisi, animasi, soundtrack epic, you see big girl

\section{PENDAHULUAN}

Animasi Attack on Titan merupakan adaptasi dari komik dengan judul serupa yang ditulis oleh Hajime Isayama sejak tahun 2009. Animasi ini menceritakan perlawanan manusia terhadap penjajahan raksasa yang telah berlangsung selama ratusan tahun, sehingga pada sepanjang cerita memperlihatkan adegan, suasana, dan emosi yang tidak lepas dari aksi kepahlawanan, perjuangan, serta pertarungan antara manusia dan raksasa. Alur ceritanya mengambil waktu pada tahun 845 dan bertempat di belahan dunia barat jika dilihat dari namanama karakternya, seperti Eren Yeager dan Levi Ackerman. Animasi ini mengusung genre action-dark fantasy, yaitu pengembangan aliran fantasi yang menggabungkan unsur action, fantasi, dan horror.

Sebagai genre yang diproduksi secara lebih meluas dalam industri perfilman, genre action, comic books, dan fantasy memerlukan musik cinematic yang mampu mengundang imajinasi penonton melalui perpaduan audio dan visualnya agar mampu mencapai tempat, karakter, dan dunia imajiner pada film-film tersebut (Buhler, 2017:5), seperti halnya pengerjaan soundtrack oleh Hans Zimmer pada film animasi Kung Fu Panda (2017) (Lehman, 2017:27). Hal ini sejalan dengan peranan vital musik terhadap kekuatan penyampaian sebuah film, terutama 


\section{Metta Muliani \\ Analisis Komposisi Soundtrack Epic "You See Big Girl” Karya Hiroyuki Sawano dalam Serial Animasi Attack on Titan}

dalam membentuk kesan dan pemahaman kita terhadap alur cerita dan karakter, bahkan tanpa kita sadari (Tan, 2016:23). Karena itulah, film dengan genre-genre yang disebutkan sebelumnya, umumnya diiringi musik-musik cinematic, yang kemudian dikenal dengan istilah musik epic.

Secara harfiah epic bermakna syair kepahlawanan. Namun, di era modern, kata epic digunakan untuk memaknai sesuatu yang sifatnya 'luar biasa' sehingga menggeser makna epic yang sebenarnya (Lehman, 2017:31). Demikian seiring berbagai perkembangan yang terjadi, terlepas dari fungsinya pada film aksi, sejarah, dan fantasi, musik epic dikenal sebagai musik yang keras (loud), berani (bold), semangat (vibrant), dan menggugah (evocative) (Werlé, 2014:50). Pengolahan ritme, melodi, harmoni, dan dinamik dapat dipadukan dengan berbagai cara untuk menciptakan berbagai jenis situasi klimaks serta memicu kekuatan musikal pada suatu karya musik (Persichetti, 1961:226). Oleh karena itulah pengkajian mengenai elemenelemen musikal dalam suatu musik epic diperlukan.

Musik pada film erat kaitannya akan waktu, kejadian, tempat, maupun suasana pada film tersebut (Anwar et al., 2020:246). Terlebih lagi, soundtrack menyediakan ruang bagi musik untuk didengar sebagai musik itu sendiri, terlepas dari perannya selama beberapa detik dalam adegan yang mungkin tidak disadari oleh sebagai besar penontonnya (Donelly, 2015:108). Meski demikian, pembahasan ilmiah mengenai soundtrack animasi masih sangat jarang, terutama dengan jenis musik epic yang hanya diidentifikasi sebagai musik yang kuat, megah, serta berkaitan dengan pertarungan. Mark Brownrigg dalam disertasinya, "Film Music and Film Genre", mengemukakan tentang adanya penggunaan brass, choir, perkusi, dan sudden silence pada musik pertarungan dan peperangan. Salah satu penelitian spesifik mengenai soundtrack epic adalah disertasi "The Music of World of Warcraft: Lore of Epic Music" oleh Xavier Derrick Werlé yang menganalisis komposisi soundtrack epic pada PC-Game World of Warcraft. Penelitian tersebut membuktikan bahwa soundtrack epic memiliki (1) penggunaan brass, perkusi, high strings, choir; (2) poliritmik; (3) polimeter; (4) repetitive line; (5) layering; (6) big crescendo dan sudden silence; (7) kecenderungan penggunaan tonalitas minor.

Penelitian ini membahas salah satu soundtrack epic dalam animasi Attack on Titan berjudul YouSeeBIGGIRL/T:T. Untuk selanjutnya, penyebutan judul soundtrack akan menggunakan kata You See Big Girl. Soundtrack ini memiliki penggunaan perkusi secara repetitif yang mengiringi melodi, penggunaan synthesizer yang dipadukan dengan instrumen tradisional, pengolahan melodi sederhana yang terdengar padat, juga penataan bentuk dan struktur musik tertentu. Soundtrack ini merupakan karya Hiroyuki Sawano, seorang komposer Jepang di bawah label Columbia Records yang juga mengerjakan soundtrack animasi Guilty Crown dan Kabaneri Iron Fortress. Permasalahan yang diajukan pada penelitian ini adalah bagaimana pengolahan elemen musik epic pada soundtrack You See Big Girl? Penelitian ini diharapkan dapat menyajikan referensi mengenai soundtrack epic, terutama soundtrack animasi, serta deskripsi mengenai elemen-elemen dalam musik epic.

\section{METODE}

Penelitian kualitatif merupakan penelitian yang berusaha memahami fenomena atau perilaku pada subjek penelitian dengan mendeskripsikannya melalui kata-kata (Moleong, 2004:6). Penelitian ini bermaksud untuk memahami kualitas epic dalam soundtrack You See Big Girl dengan mendeskripsikan komposisi musik serta elemen epic di dalamnya. Pengumpulan data diperoleh melalui studi literatur, studi diskografi, dan observasi. Studi literatur bertujuan untuk menemukan teori atau landasan berpikir yang tepat untuk mendukung penyelesaian masalah (Subana, 2011:77). Peneliti mengumpulkan teori yang berhubungan dengan pembahasan komposisi musik dan soundtrack epic. Studi diskografi merupakan aktivitas analisis, deskripsi, dan penguraian dari bunyi yang direkam (Stevenson, 1972:101), maka peneliti mentranskrip soundtrack You See Big Girl dengan program Sibelius untuk memudahkan proses pengkajian bentuk, struktur, dan elemen musikal didalamnya. Observasi pada audio soundtrack dan video animasi bertujuan untuk mengetahui penggunaan instrumen atau penggunaan bagian tertentu dari soundtrack You See Big Girl pada adegan yang diiringinya. 
Teknik analisis dilakukan dengan terlebih dahulu mereduksi data atau memilih hal pokok yang berhubungan dengan penelitian (Sugiyono, 2012:338), di antaranya adalah audio dan partitur soundtrack, serta literatur komposisi musik, musik epic, dan soundtrack film. Peneliti menggunakan teori Brownrigg, Jarret \& Day, Prier, dan Jamalus dalam mengkaji bentuk dan struktur komposisi musik. Kajian elemen musik epic pada soundtrack ini menggunakan teori dari Lehman dan Derrick Werlé, yang terdiri dari: 1) tonalitas minor; 2) poliritmik; 3) big crescendo dan sudden silence; 4) instrumentasi yang berkaitan dengan pertarungan; 5) layering; 6) aksen marcato; 7) ostinato; 8) tema abstrak; dan 9) sekuen.

\section{HASIL DAN PEMBAHASAN \\ YouSeeBIGGIRL/T:T}

You See Big Girl dirilis sebagai soundtrack ketiga dalam Attack on Titan Original Soundtrack Album Season 2 pada tahun 2017. Soundtrack merupakan lagu yang dibuat khusus sesuai dengan kisah film yang bersangkutan (Phetorant, 2020:93). Berdasarkan deskripsi pada Attack on Titan Season 2 Original Soundtrack Album, YouSeeBIGGIRL/T:T merupakan arti dari Ymir Titan/Titan Transformation. BIGGIRL berarti raksasa perempuan, sementara YouSee menyiratkan nama manusia raksasa pertama dalam serial animasinya (dibaca Yumiru, yang merupakan bahasa Jepang dari kata 'YouSee'), meski fakta tersebut belum disampaikan pada serial musim kedua animasi Attack on Titan. Sementara "T:T" merupakan singkatan dari Titan Transformation, mengingat soundtrack ini juga mengiringi adegan transformasi raksasa. Dengan demikian, soundtrack ini termasuk jenis musik programa appellative, yaitu musik programa dengan judul yang menyiratkan nama karakter (Stein, 1979:173).

\section{Analisis Struktur Komposisi You See Big Girl}

Menurut Prier, analisis musik berarti memperhatikan detil musik dengan melupakan keseluruhan suatu karya musik (1996:1). Sementara Jamalus (1988:1) menyampaikan bahwa musik ialah karya seni berupa komposisi musik yang mengungkapkan ide atau gagasan penciptanya melalui penyatuan bentuk, struktur, irama, melodi, harmoni, serta ekspresi. Berdasarkan definisi tersebut, maka analisis komposisi musik dapat diartikan sebagai usaha mendalami komposisi karya musik dengan mengkaji bentuk, struktur, serta unsur-unsurnya.

Bentuk musik populer umumnya terdiri dari intro, verse, dan chorus (Jarret \& Day, 2008:154). Namun bentuk musik film tidak memiliki struktur formal yang bergerak dari verse ke chorus kemudian bridge, menjadikan musik pada film tidak memiliki mekanisme yang menghubungkan bagian-bagiannya seperti musik genre lain (Brownrigg, 2003:34-36). Hal ini disebabkan oleh kecenderungan musik film sebagai reaksi atau respon musikal terhadap film yang diiringinya (Rosar, 2002:4). Sama halnya dengan soundtrack You See Big Girl yang terdiri dari dua bagian besar, yaitu Apple Seed dan Vogel im Käfig yang dibedakan oleh tonalitas, nilai tempo, instrumentasi, serta memiliki susunan introduksi, verse, chorus, dan outro masing-masing.

\section{1) Apple Seed}

Apple Seed merupakan soundtrack utama dari musim ketiga Attack on Titan yang telah dirilis sejak musim keduanya sebagai bagian pertama dari You See Big Girl. Bagian ini dimainkan dalam tonalitas $\mathrm{C}$ minor dengan tempo $80 \mathrm{bpm}$, dan tersusun dari Introduksi Verse - Chorus - Outro. Introduksi dibawakan oleh brass, strings, dan choir yang memainkan melodi berbeda pada motif yang sama sehingga membentuk harmoni. Introduksi berlangsung selama sembilan birama dan diakhiri dengan kadens menyimpang pada akor Ab mayor 7.

Verse diawali dan diakhiri dengan tema abstrak, yaitu perulangan motif pendek $\mathrm{n} 1$ pada sepanjang periode kalimatnya. Tema abstrak merupakan motif pendek yang berulang dan tidak berorientasi seperti motif pada umumnya, dan dalam musik epic berfungsi untuk menciptakan ketegangan pada bagian praklimaks (Lehman, 2017:36). Motif n1 dimainkan oleh synthesizer dengan efek gema atau reverb, dan menjadi suatu tema abstrak karena memiliki melodi yang berulang dan berlangsung selama satu periode kalimat.

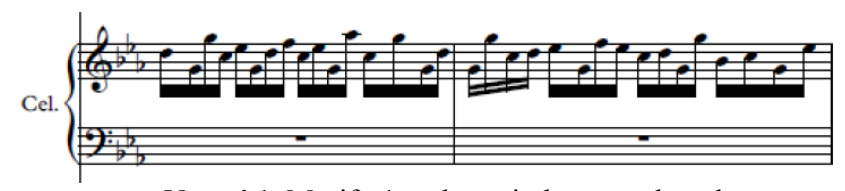

Notasi 1. Motif $n 1$ pada periode tema abstrak.

Verse terdiri atas delapan birama dan dibawakan secara poliritme, yang dapat dilihat dari adanya counter melody. Dalam orkestrasi, counter melody memiliki nada yang sama 


\section{Metta Muliani \\ Analisis Komposisi Soundtrack Epic "You See Big Girl” Karya Hiroyuki Sawano dalam Serial Animasi Attack on Titan}

dengan unsur nada dari akor yang dimainkan pada melodi asli, serta berfungsi sebagai pendukung pembawaan melodi aslinya (Caturono, 2019:38-39). High strings dan trumpet memainkan melodi utama, sementara horn memainkan motif yang berbeda dari melodi utama sebagai melodi counter, serta trombone mempertegas melodi counter yang dibawakan horn dengan mengisi melodi-melodi pada akhir kalimat. Tema abstrak kemudian beralih menjadi pengiring dengan dinamik mezzo piano, sementara melodi pokok dimainkan dengan dinamik forte. Verse diakhiri dengan akor $\mathrm{v}$ minor atau $G$ minor, menunjukkan adanya penggunaan half cadence dan menimbulkan efek 'koma' (Jamalus, 1988:37).

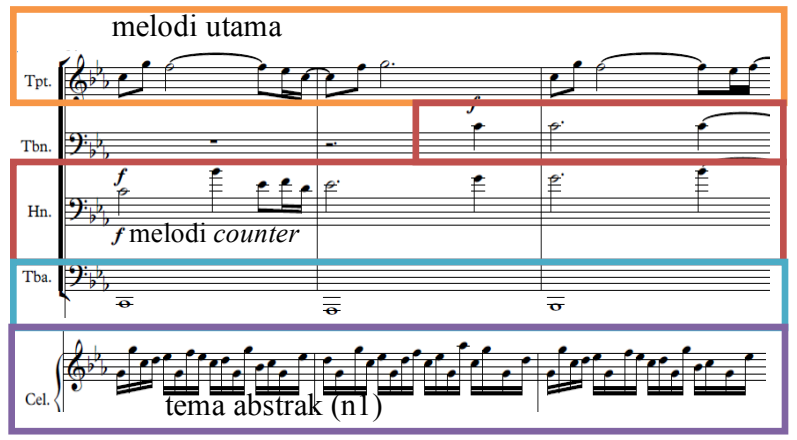

Notasi 2. Verse yang diiringi tema abstrak.

Bagian ini kembali dilanjutkan dengan tema abstrak selama delapan birama dan memiliki crescendo panjang selama enam birama pada instrumen perkusi yang mengiringi tema abstrak. Berhentinya iringan perkusi pada ketukan terakhir menegaskan pergantian bagian menuju chorus, menggantikan peran kadens dan ketiadaan perubahan pola irama pada motif $n 1$ atau tema abstrak yang terus berulang.

Chorus merupakan bagian inti cerita dari lagu, sementara pengulangan chorus berarti pengembangan chorus sebagai inti lagu (Jarret \& Day, 2008:154). Apple Seed memiliki chorus dengan periode ganda, dengan tema abstrak dalam dinamik mezzo piano yang mengiringinya. Kedua periode diawali oleh cymbal sebagai penanda periode baru dan diakhiri dengan akor $\mathrm{Bb}$ mayor untuk menjembatani akor $\mathrm{C}$ minor pada periode selanjutnya. Melodi pada Periode A hanya dibawakan oleh high strings dan diiringi synthesizer yang memainkan motif $\mathrm{n} 1$ atau tema abstrak, gitar yang mempertegas progresi akor, serta perkusi. Sementara Periode A' setingkat lebih memuncak karena memiliki choir yang menyanyikan melodi utama sehingga mempertegas dan mempertebal melodi dibandingkan Periode A, serta instrumen brass yang memainkan melodi kedua dengan motif quaver yang kontras dari motif triplet pada melodi utama. Perilaku ini memberi variasi berupa pemerkayaan ritme dan warna suara pada pengulangan Chorus karena memiliki poliritme.

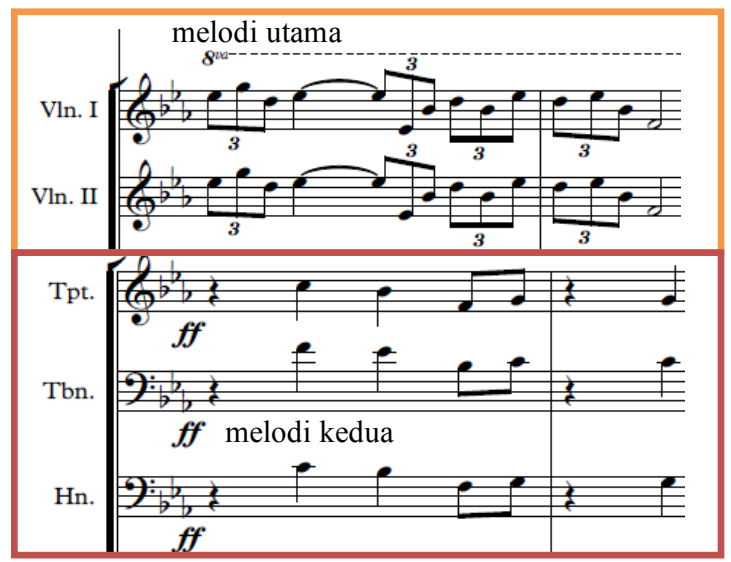

Notasi 3. Poliritmik pada Periode A'.

Outro terdiri dari delapan birama dengan empat birama pertama yang merupakan repetisi dari tema abstrak namun dengan iringan low strings pada akor C minor dan mengalami diminuendo pada awal frase konsekuennya. Setelah tema abstrak dan strings mengalami fade out, empat birama selanjutnya menyisakan iringan perkusi dengan pola yang sama dengan Introduksi dan ditutup fill untuk mengakhiri bagian Apple Seed.

\section{2) Transisi}

Transisi merupakan birama kosong selama empat ketukan penuh. Pada dasarnya Apple Seed dan Vogel im Käfig adalah dua lagu yang berbeda, dan mengingat perbedaan tonalitas dan nilai tempo dari keduanya, maka pemilihan transisi ini adalah alternatif untuk menghindari transisi secara harmoni.

\section{3) Vogel im Käfig}

Vogel im Käfig merupakan soundtrack utama dari Attack on Titan $1^{\text {st }}$ Season pada tahun 2013. Pada You See Big Girl, Vogel im Käfig diaransemen sebagai bagian kedua dengan tonalitas A minor dan tempo $86 \mathrm{bpm}$. Vogel im Käfig tidak dibawakan secara instrumental seperti Apple Seed, tetapi memiliki lirik yang dinyanyikan oleh solo alto. Bagian ini tersusun dari Introduksi - Verse I - Verse II - Bridge Chorus I - Interlude - Chorus II - Outro. Pada Introduksi, melodi utama dibawakan oleh solo 
vokal, choir, dan high strings. Dengan dibawakannya melodi secara unison oleh sebagian besar instrumen menciptakan kesan ramai dan menimbulkan warna suara tertentu dari penggabungan instrumen yang berbeda sehingga memicu kompleksitas (Putra, 2019: 64). Solo vokal menyanyikan lirik secara syllabis, yaitu jenis nyanyian yang hanya menggunakan satu suku kata dalam satu nada (Karl Edmund Prier, 2014:16). Nyanyian syllabis terdapat pada musik Greogorian untuk upacara pemakaman sekitar tahun 800-an dan juga requiem Dies Irae dalam Liber Usualis yang dibawakan secara monofon (Karl Edmund Prier, 2014:83-86; Stein, 1979:180). Meskipun tidak murni dibawakan secara monofon, pemilihan gaya syllabis dalam tangga nada minor serta iringan yang minimalis merupakan usaha untuk menghubungkan musik dengan masa yang terdapat pada alur cerita, yaitu tahun 800-an, serta suasana duka pada cerita mengingat tema ini mengiringi peristiwa kematian ibu Eren, Carla, pada episode pertama. Melodi diiringi low strings yang memainkan nada rendah A untuk mempertegas tonalitas minor, perkusi, dan synthesizer serupa suara sirine yang memainkan tangga nada A minor secara glissando. Introduksi diakhiri dengan kadens otentik pada tingkat $i$.

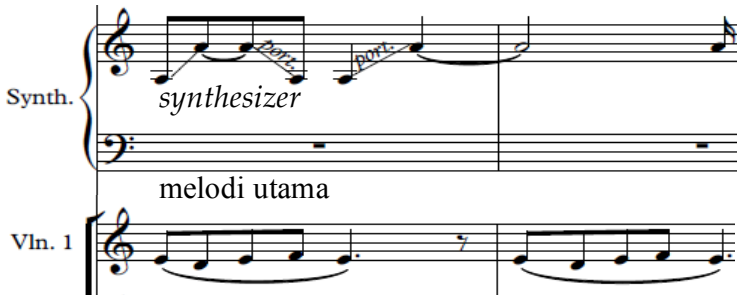

Notasi 4. Pola permainan synthesizer Vogel im Kafig.

Verse I merupakan bagian minim iringan yang terdiri dari satu periode dan diakhiri kadens sempurna, sementara Verse kedua merupakan periode ganda yang dibawakan secara ostinato, yaitu perulangan melodi sederhana dan berulang yang dibangun oleh repetisi dan intensitas dari motif pendek (Lehman, 2017:29). Periode pertama dari ostinato diakhiri dengan kadens menyimpang pada tingkat VII atau G mayor, sedangkan periode kedua diakhiri dengan harmonisasi dari akor Em untuk komponen bass dan B diminished untuk kelompok melodi sehingga membentuk harmoni disonan antara nada $\mathrm{E}$ dan $\mathrm{F}$. Adapun harmoni disonan dapat diasosiasikan dengan suasana gelisah (Rohmatullah, 2020: 130).

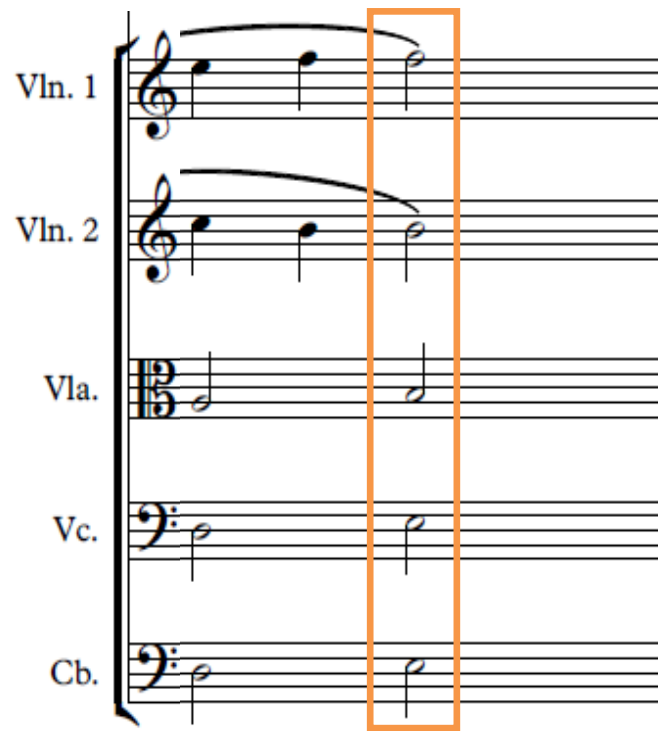

Notasi 5. Harmonisasi E minor dan Bdim pada birama terakhir ostinato.

Sebelum Chorus, terdapat bagian yang berbeda dari verse dan chorus yang membangun tensi naik antara verse sebelum menuju chorus. Bagian ini disebut sebagai bridge, yaitu bagian yang bisa jadi instrumental maupun berlirik dan berbeda dari chorus maupun verse (Jarret \& Day, 2008:154). Bridge diawali dengan piano subito selama dua birama, yaitu keheningan mendadak untuk semua instrumen selain low choir dan snare drum, sebagai alternatif untuk menghubungkan suasana gelisah yang ditimbulkan oleh harmoni disonan Em dan Bdim pada birama sebelumnya dengan Bridge yang diawali akor Am. Pada bagian ini, solo vokal bernyanyi dengan humming, synthesizer memainkan pola permainan yang sama dengan bagian sebelumnya, yaitu scale A minor dengan dinamik forte sehingga mendominasi Bridge melebihi melodi vokal. High strings memainkan sekuens selama empat birama dengan aksen marcato dan poco crescendo untuk membangun transisi naik sebelum chorus. Sekuens berakhir pada ketukan terakhir menjelang chorus, menciptakan efek sudden silence karena jeda sesaat sebelum pergantian tema akan membuat bagian selanjutnya terasa kuat dan berdampak (Persichetti, 1961:227).

Bagian berikutnya merupakan Chorus yang terdiri dari delapan birama. Melodi utama dari Chorus dibawakan oleh strings dan choir yang mengimitasi melodi utama oleh solo vokal. Bagian ini didominasi oleh melodi yang padat dibandingkan variasi ritme maupun harmoni, dan diakhiri dengan kadens menyimpang pada 
akor FMaj7. Instrumen gitar bass dan drum baru mulai dimainkan pada Interlude yang dimainkan dengan dinamik fortissimo. Crash cymbal mengawali frase Interlude, menggantikan peran cymbals dan gong sebagai pembuka frase seperti bagian sebelumnya. Gitar bass mempertegas akor bersama low strings dan gitar agar dapat mengimbangi permainan drum.

Melodi pada Interlude terbagi menjadi tiga kelompok, yaitu solo vokal, melodi pengiring 1 dan melodi pengiring 2. Solo vokal berimprovisasi dengan artikulasi "ah", "hu", dan "oh". Kelompok pengiring pertama dimainkan oleh high strings dan choir sehingga menghasilkan iringan yang solid. Iringan melodi selanjutnya dimainkan trombone sebagai melodi counter atau perlawanan dari melodi high strings dan choir. Pada akhir frase, trombone mempertegas akhir kalimat dengan memainkan nada yang sama dengan melodi pengiring high strings dan choir. Frase ini diakhiri dengan tingkat $\mathrm{V}$ dominan 7 , sehingga memberi efek 'koma' sebagai transisi menuju Chorus II. Adapun instrumen drum yang memainkan fill-in pada kadens merupakan penegas adanya transisi menuju Chorus II.

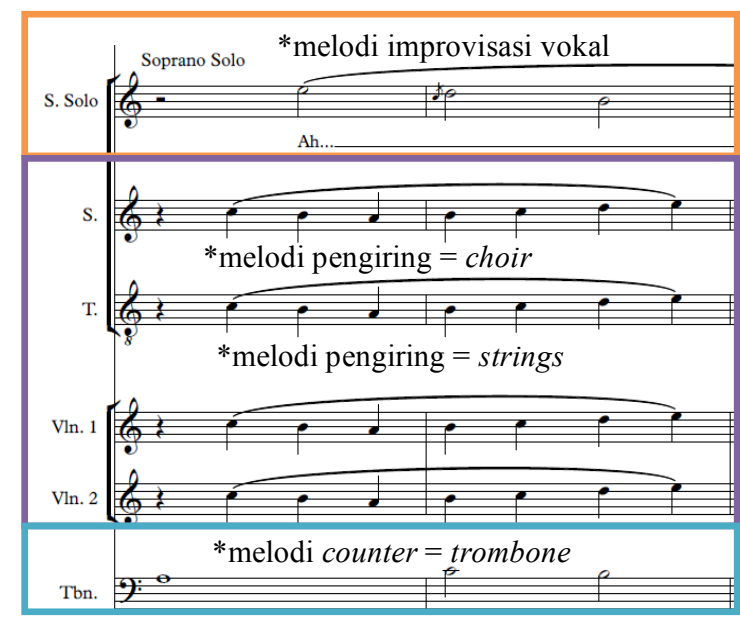

Notasi 6. Poliritme pada Interlude.

Interlude dilanjutkan oleh repetisi Chorus dengan variasi pada iringannya, yaitu adanya permainan drum dan gitar dengan pola yang sama seperti Interlude. Chorus tidak diakhiri dengan kadens otentik atau sempurna, melainkan akor FMaj7 dengan fill-in dari drum yang mempertegas pergantian periode. Outro terdiri dari empat birama yang hanya terdiri dari iringan drum yang sama dengan Interlude dan Chorus tanpa tema melodis.

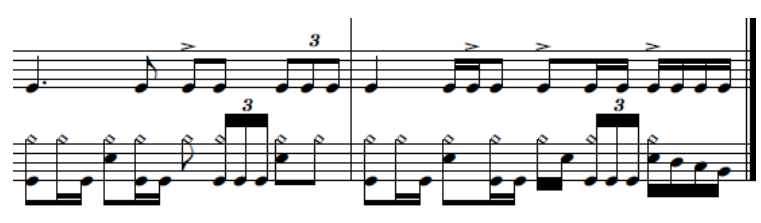

Notasi 7. Pola permainan drum pada dua birama terakhir Outro.

\section{Elemen Musik Epic pada Soundtrack "You See Big Girl"}

Menurut Werlé, musik epic merupakan musik yang menggambarkan kemuliaan, keagungan, kehebatan, bahkan terkadang kerinduan melalui musik yang keras (loud), berani (bold), semangat (vibrant), dan menggugah (evocative) (2014: 50). Werlé juga menyebutkan bahwa musik epic umumnya memiliki tonalitas minor, big crescendo, sudden silence, poliritmik, dan instrumentasi yang berkaitan dengan pertarungan (2014:81-99). Sementara Lehman (2017:29-44) menyatakan bahwa ostinato, marcato motto, dan abstract anthem merupakan beberapa unsur yang terdapat dalam pengerjaan musik epic komposer Jerman, Hans Zimmer. Pembahasan berikut akan difokuskan pada pengolahan elemen-elemen tersebut dalam soundtrack You See Big Girl.

\section{1) Tonalitas}

Sebagian besar musik epic memiliki tonalitas minor karena perang bukanlah hal yang menyenangkan, kecuali ketika musik menggambarkan suasana kemenangan pasca pertarungan atau misi yang terselesaikan (Werlé, 2014:99). Tonalitas You See Big Girl adalah C minor dan A minor. Dalam cerita, soundtrack ini mengiringi transformasi raksasa Ymir sebelum ia melawan puluhan raksasa liar seorang diri untuk melindungi teman-temannya. Sementara Vogel im Käfig merupakan tema yang mengiringi peristiwa kematian Carla Yeager, ibu dari tokoh utama, dan juga pertempuran Warriors melawan tentara Survey Corps. Dengan demikian, tonalitas minor dalam soundtrack ini merupakan usaha untuk mengiringi suasana tidak menyenangkan tersebut.

\section{2) Poliritmik}

Poliritmik adalah kombinasi dari dua atau lebih pola ritme yang kontras sehingga mengaburkan ekspekstasi akan ritme yang seharusnya, serta memicu kegelisahan karena kompleksitas ritme, melodi, maupun iringan dari suatu bagian (Werlé, 2014:81). Poliritmik tidak terjadi pada sepanjang lagu, melainkan pada 
bagian-bagian tertentu seperti variasi pada pengulangan Chorus dari Apple Seed, yang dapat dilihat pada Notasi 3. Pada bagian tersebut, melodi utama dibawakan oleh high strings dengan pola ritme triplet dan sinkopasi, sedangkan melodi brass 'menentang' melodi utama dengan memainkan not seperempat dan not seperdelapan untuk mengiringi melodi utama. Poliritmik memungkinkan penyampaian ragam baris melodi dan ritme yang dimainkan oleh instrumen dengan warna suara yang kontras terdengar tegas.

\section{3) Big Crescendo dan Sudden Silence}

Big crescendo berfungsi untuk menciptakan ketegangan atau tensi dengan menyusun crescendo panjang dan konsekuen pada beberapa birama, sementara sudden silence merupakan interupsi mendadak pada musik berupa keheningan atau penurunan dinamik yang drastis (Werlé, 2014:81). Pada bagian Apple Seed, yaitu tema abstrak menjelang Chorus, terdapat crescendo selama enam birama pada instrumen tom-toms. Resolusi dari big crescendo seharusnya adalah forte atau fortissimo, namun big crescendo diakhiri oleh sudden silence satu birama sebelum Chorus. Hal ini membuat Chorus menjadi lebih 'berdampak', karena sudden silence yang mengawali bagian klimaks akan menetralkan kekacauan yang dibangun oleh crescendo, forte, atau sound effect keras lainnya (Brownrigg, 2003:208-209). Jeda dan istirahat setelah pola ritme yang panjang dan konsisten lebih efektif dalam memberi penekanan dan kekuatan pada musik daripada tetap dimainkan tanpa jeda atau sudden silence (Persichetti,

1961: 227). Dengan begitu, dinamik forte pada Chorus sebagai bagian puncak menjadi lebih berdampak, karena efek drastis dari sudden silence membuat bagian tersebut tidak terprediksi sehingga mengarahkan fokus pendengar pada bagian setelahnya.

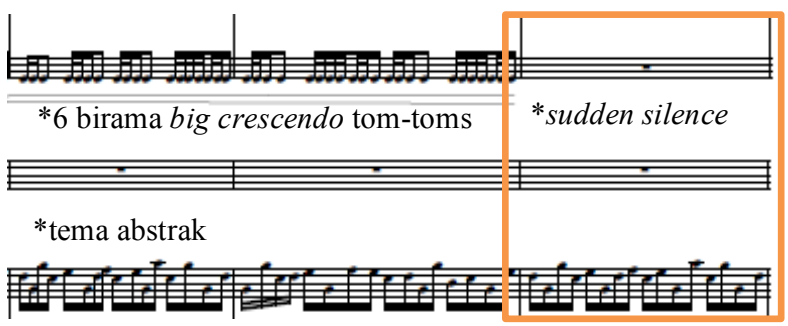

Notasi 8. Big crescendo dan sudden silence sebelum Chorus I pada Apple Seed.

\section{4) Instrumentasi}

Instrumentasi berpengaruh pada bagaimana suasana yang dibangun dalam karya musik (Werlé, 2014:90). Musik epic sebagai musik yang menggambarkan kemegahan, keberanian, ataupun aksi kepahlawanan tentu memerlukan instrumen dengan keterkaitan pada situasi tersebut. Perkusi dikenal sebagai salah satu instrumen yang telah berkaitan dengan pertarungan atau peperangan sejak dulu, seperti drum Taiko yang digunakan untuk memberi sinyal mundur atau serang oleh pasukan Jepang, atau drum oleh tentara Eropa yang sejak era pertengahan digunakan sebagai instrumen pada musik mars (Sterling, 2008:286-287; Turnbull, 2012:27-28). Hal inilah yang membuat perkusi memiliki warna suara yang berkaitan dengan situasi epic.

Penggunaan perkusi pada You See Big Girl terdapat pada sepanjang lagu. Perkusi yang digunakan adalah instrumen mars, yaitu tomtoms, snare drum, bass drum sebagai dasar iringan ritme yang cenderung repetitif. Cymbal dan gong dimainkan pada setiap pergantian frase untuk menegaskan bagian tersebut. Sementara Vogel im Käfig, meski menggunakan modern drum kit, lagu ini diawali dengan iringan drum tradisional tom-toms dan snare drum. Pola iringan perkusi yang berulang dibubuhi ketegasan dengan aksen marcato berfungsi untuk meningkatkan intensitas dramatis yang ada pada musik film (Lehman, 2017:26).

Warna suara brass yang cemerlang dan keras memungkinkan bunyinya terdengar dalam jarak jauh sehingga telah digunakan oleh pasukan untuk berkomunikasi sejak dulu, seperti trompe de chasse pada masa Louis XV yang digunakan untuk berburu atau la cor de chasse digunakan dalam komunikasi antar pasukan militernya (Werlé, 2014:108). Selain itu, Berlioz dalam Brownrigg (2003:20) menyatakan bahwa trumpet memiliki karakter suara yang mulia (noble) dan cemerlang (brilliant) sehingga cocok untuk mengekspresikan situasi perang yang megah, semangat membela diri masing-masing kelompok, melambangkan teriakan amarah, pembalasan, serta seruan kemenangan. Dengan warna suara yang khas dan tegas tersebut, instrumen brass dapat digunakan pada baik pada melodi utama maupun barisan melodi yang 'melawan' melodi utama. Dengan memainkan ritme-ritme yang kontras, melodi yang dibawakan lebih lebih kaya, kuat, dan tegas karena timbre khas dari brass. Karakter suara 


\section{Metta Muliani \\ Analisis Komposisi Soundtrack Epic "You See Big Girl” Karya Hiroyuki Sawano dalam Serial Animasi Attack on Titan}

dan eratnya kaitan antara brass dengan pertarungan menjadikan brass menjadi salah satu elemen penting dalam musik epic, baik sebagai melodi utama maupun melodi counter.

Penggunaan choir pada karya ini berkaitan dengan genre pada cerita, karena warna suara choir sangat efektif untuk menggambarkan kesan 'pengorbanan' terutama pada film peperangan, menggambarkan penghormatan yang besar, kekuatan, konflik, dan keharusan untuk berkorban (Brownrigg, 2003:29). Pada soundtrack ini choir berperan membawakan melodi utama dan membangun harmoni, seperti strings dan juga brass. Perbedaannya adalah choir merupakan instrumen dari manusia (human instrument) sehingga sesuai untuk mewakili aksi kepahlawanan dan pengorbanan yang dilakukan oleh manusia.

Dalam suatu karya musik orkestra, strings merupakan salah satu instrumen yang dibutuhkan, seperti violin, baik sebagai melodi utama maupun instrumen pendamping (Kusuma, 2019:107). Untuk memperkuat pembawaan violin, perlu adanya instrumen berjangkauan nada rendah yang melandasinya, yaitu instrumen low strings. Keberadaan instrumen strings memungkinkan warna suara yang dibawakan terdengar luas untuk menghadirkan kesan megah dan ramai. Hal ini didukung oleh wilayah nada yang luas yang dimiliki oleh keluarga strings, mulai dari violin, viola, cello, hingga contrabass.

Bunyi elektronik bertujuan untuk menghadirkan suara unik dan mendukung penyesuaian musik dengan skenario (Walus, 2012:61). Instrumen elektro juga memberi lebih banyak pilihan bagi komposer untuk menciptakan efek tertentu tanpa perlu memikirkan jangkauan nada atau teknik seperti halnya instrumen tradisional (Werlé, 2014:9091). Synthesizer mengisi sebagian besar bagian Apple Seed dengan memainkan G phrygian, baik sebagai tema maupun pengiring. Sedangkan pada bagian selanjutnya, yaitu Vogel im Käfig, synthesizer memainkan glissando dalam scale A minor. Kedua pola permainan synthesizer ini digunakan pada sepanjang soundtrack terlepas dari koherensinya dengan progresi akor. Meski pengolahan demikian menabrak alur melodi, penggunaan instrumen ini mampu memperkaya melodi dan juga variasi warna suara.

\section{5) Layering}

Pada musik epic, teknik yang digunakan untuk mengolah melodi sederhana atau iringan repetitif adalah layering, yaitu menyusun melodi yang sama dalam jangkauan nada berbeda baik lebih tinggi maupun lebih rendah sehingga menghasilkan warna suara yang lebih mendalam, natural dan realistis, daripada melodi yang hanya dimainkan instrumen tunggal (Werlé, 2014:71). Layering digunakan pada suara choir dan strings. Strings membentuk harmoni dengan memanfaatkan layering karena wilayah nada yang luas memungkinkan strings untuk memenuhi ruang melodi. Sama halnya dengan strings, layering pada choir juga disusun dengan jarak oktaf sehingga memperluas dan memperkuat efek penyampaian melodi utama yang dinyanyikan oleh solo vokal. Layering pada strings dan choir dapat dilihat pada bagian ostinato atau Verse II dari Vogel im Käfig untuk mendukung penyampaian melodi seperti pada notasi berikut.

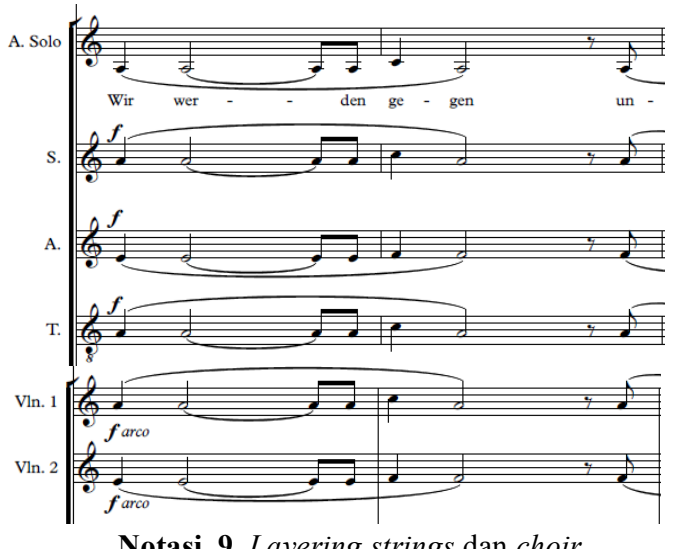

Notasi 9. Layering strings dan choir.

\section{6) Aksen Marcato}

Pada musik film, aksen marcato dan pola berulang pada perkusi berfungsi untuk membangun intensitas ketegangan pada musik (Lehman, 2017:46). Pengolahan aksen terlihat pada ritme yang dibawakan oleh tom-toms dipertegas oleh aksen marcato dari bass drum dan snare drum pada Notasi 10. Pengolahan aksen marcato menjadikan iringan perkusi tidak monoton karena memiliki ritme yang khas,

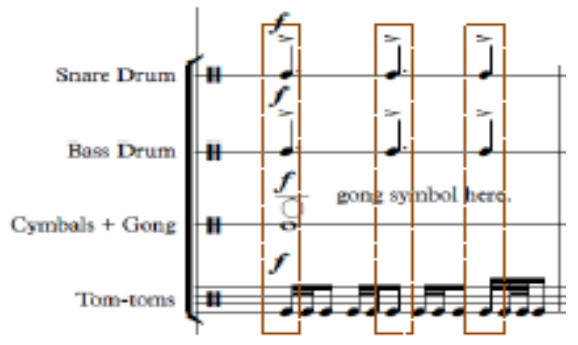

Notasi 10. Aksen marcato pada perkusi. 
dalam hal ini tekanan-tekanan pada ritme gantung dari iringan tom-toms.

\section{7) Ostinato}

Pada musik epic, ostinato berfungsi untuk menciptakan suasana tenang dari gerakan melodi sederhana yang berulang dan berlangsung lama, sehingga membuat musik seolah menjauh dari ketegangan yang tidak terprediksi, karena sebenarnya ostinato bagaikan 'jebakan' untuk membuat ketegangan yang dipersiapkan semakin berdampak (Lehman, 2017:29). Pada Vogel im Käfig, ostinato panjang selama dua periode diakhiri dengan sudden silence selama dua birama sebelum memasuki Introduksi II. Ostinato membuat perubahan pada Bridge menjadi lebih berdampak, karena ketika pergerakan nada stabil berlangsung cukup lama, perubahan tema atau dinamik akan menciptakan ketegangan musikal karena tidak terprediksi (Lehman, 2017:30).

\section{8) Tema Abstrak}

Tema abstrak menghindari penggunaan melodi konvensional yang menarik dan berorientasi seperti musik-musik yang pernah ada dengan menyusun motif-motif pendek yang berulang pada birama (Lehman, 2017:42). Tema abstrak pada soundtrack ini tersusun atas memiliki motif pendek $\mathrm{n} 1$ yang memenuhi ruang kalimat dan periode, tepatnya sebelum Chorus dari bagian Apple Seed. Motif ini dimainkan dengan synth-glockenspiel yang diberi efek gema (reverb) dengan dinamik mezzo piano, menjadi suatu tema abstrak karena dimainkan secara repetitif dan berlangsung selama satu periode kalimat. Sepanjang delapan birama menuju chorus sebagai bagian klimaks, motif ini diiringi dengan perkusi yang mengalami big crescendo meski dengan pola repetitif. Adapun abstraksi tema ini mengiringi percakapan terakhir Bertholdt Hoover dan Armin Arlert pada Shiganshina Arc tepat sebelum ia diserang oleh Mikasa Ackerman. Abstraksi tema membangun ketegangan yang disesuaikan pada awal cerita atau pra-klimaks dengan cara yang berbeda dari klimaks yang menggebu-gebu, sehingga membuat bagian

awal menjadi sama pentingnya dengan bagian klimaks (Lehman, 2017:44). Dengan ritmik semiquaver yang berulang sepanjang periode kalimat, tema abstrak ini memang diperuntukkan pada suasana yang bukan klimaks atau mungkin pra-klimaks, karena ritmik yang berulang menggambarkan suasana statis atau tenang (Sitompul, 2017:23). Hasilnya, Chorus yang dimainkan setelah tema abstrak terdengar kuat dan tegas karena dimainkan setelah suasana statis yang ditawarkan oleh tema abstrak.

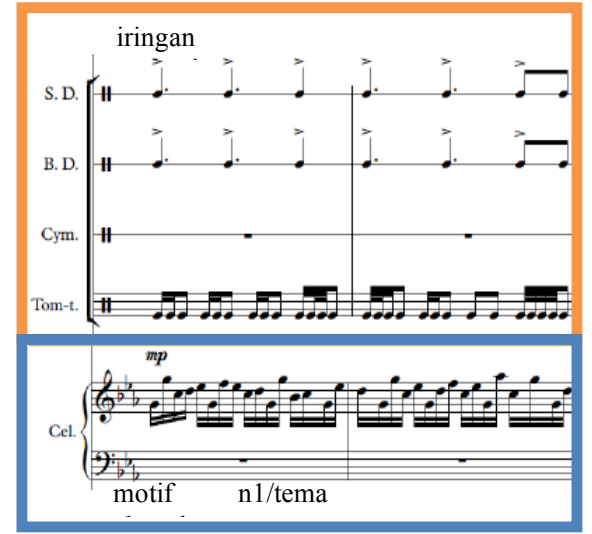

9) Sekuen

Notasi 11. Tema abstrak.

Sama halnya dengan big crescendo, sekuen dapat digunakan untuk membangun transisi naik secara bertahap sebelum bagian puncak atau klimaks (Werlé, 2014:116). High strings mempersiapkan tensi yang ada pada Chorus dengan memainkan empat birama sekuen secara staccato dan poco crescendo. Bagian ini juga diakhiri oleh rest sebagai sudden silence selama satu ketuk sebelum Chorus. Adapun accent mempertegas sekuen, karena accent menonjolkan atau menekankan nada tersebut dari nada lainnya (Husna, 2018:55).

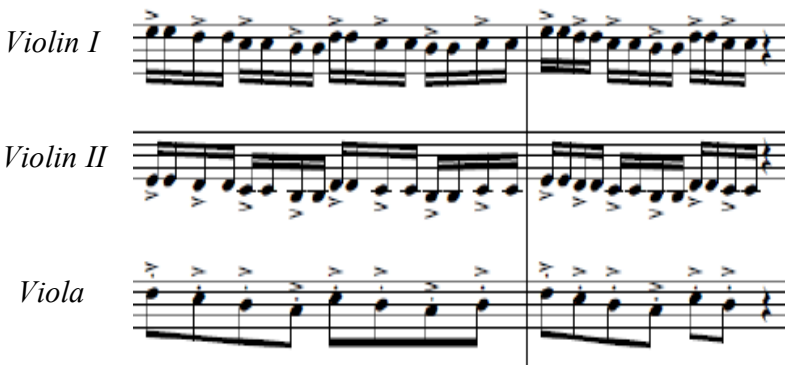

Notasi 12. Sekuen yang dimainkan strings sebagai penghantar menuju Chorus. 
Table 1. Struktur Komposisi You See Big Girl dan Elemen Epic

\begin{tabular}{ll}
\hline Bagian & Elemen Epic \\
\hline Introduksi (Apple Seed) & sudden silence; layering \\
Verse & tema abstrak; big crescendo; sudden silence \\
Chorus & marcato (perkusi); poliritme; layering \\
Outro & marcato (perkusi) \\
Introduksi ( Vogel im Käfig) & layering; \\
Verse I & marcato (perkusi) \\
Verse II & ostinato; layering \\
Bridge & sudden silence; synthesizer; sekuen; big crescendo \\
Chorus & layering; marcato (perkusi) \\
$\quad$ Interlude & poliritme \\
$\quad$ Chorus & layering; poliritme \\
$\quad$ Outro & marcato (perkusi)
\end{tabular}

\section{KESIMPULAN}

Meskipun anime berasal dari Jepang, tidak menutup kemungkinan komposer menggunakan gaya musik cinematic yang umumnya terdapat pada film action-fantasy barat, yaitu musik epic, untuk menyesuaikan musik dengan setting, suasana, maupun tempat pada cerita. Penggambaran suasana megah dan semangat pertarungan dalam musik epic didukung dengan penggunaan tonalitas minor, poliritme, layering pada barisan melodi sederhana, aksen marcato yang mempertegas iringan perkusi, dan instrumentasi yang berkaitan dengan pertarungan dan peperangan, seperti brass, perkusi, dan choir. Transisi naik dan peningkatan ketegangan antarbagian dilakukan dengan penambahan instrumen yang mendukung pemerkayaan ritme dan melodi lebih daripada bagian sebelumnya, serta memanfaatkan big crescendo, sekuen panjang, ostinato, dan tema abstrak yang diakhiri oleh sudden silence untuk menciptakan penekanan pada pergantian bagian dan transisi.

\section{DAFTAR PUSTAKA}

Anwar, A. A., Budiman, A., \& Ramdhan, Z. (2020). Kreativitas Musik Film Sang Pencerah. Jurnal Kajian Televisi Dan Film. ProTV, 4 (2), 223-246. http://jurnal.unpad.ac.id/protvf/article/vie $\mathrm{w} / 25445$

Brownrigg, M. (2003). Film Music and Film Genre. Stirling: University of Stirling.

Buhler, J. (2017). Branding the Franchise:
Music, Opening Credits, and the (Corporate) Myth of Origin. In S. C. Meyer (Ed.), Music in Epic Film: Listening to Spectacle (pp. 3-26). New York: Routledge.

Caturono, Y. (2019). Analisis Variasi Melodi dan Struktur Lagu pada Konserto Trumpet in Es Karya Joseph Haydn. Jurnal Pengkajian Dan Penciptaan Musik Virtuoso, 1 (2), 34-40. https://doi.org/http://dx.doi.org/10.26740/ vt.v2n1

Donelly, K. J. (2015). Magical Musical Tour: Rock and Pop in Film Soundtracks. New York: Bloomsbury Academic.

Husna, I. N. (2018). Analisis Teknik Permainan Biola pada Concerto in A Minor 3rd Movement RV 356 Op. 3 No. 6 Karya Antonio Vovaldi. Jurnal Pengkajian Dan Penciptaan Musik Virtuoso, 1 (2), 50-56. https://doi.org/10.26740/vt.v1n2.p50-56

Jamalus. (1988). Panduan Pengajaran Buku Pengajaran Musik Melalui Pengalaman Musik. Jakarta: Proyek Pengembangan Lembaga Pendidikan.

Jarret, S., \& Day, H. (2008). Music Compositions for Dummies. Indiana: Wiley Publishing, Inc.

Karl Edmund Prier. (2014). Sejarah Musik Jilid 1. Yogyakarta: Pusat Musik Liturgi.

Kusuma, S. R. (2019). Gaya Permainan Didiet Violin dalam Lagu "Turning Point." Jurnal Pengkajian Dan Penciptaan Musik Virtuoso, 2 (2), 106-120. 
https://doi.org/10.26740/vt.v2n2.p106-120

Lehman, F. (2017). Manufacturing the Epic Score: Hans Zimmer and the Sound Significance. In S. C. Meyer (Ed.), Music in Epic Film: Listening to Spectacle (pp. 27-55). New York: Routledge.

Moleong, L. J. (2004). Metodologi Penelitian Kualitatif. Bandung: PT Remaja Rosdakarya.

Persichetti, V. (1961). Harmony: Creative Aspects and Practice. New York: W.W. Norton \& Company.

Phetorant, D. (2020). Peran Musik dalam Film Score. Journal of Music Science, Technology, and Industry, 3(1), 91-102.

Prier, K. E. (1996). Ilmu Bentuk Musik. Yogyakarta: Pusat Musik Liturgi.

Putra, I. P. A. S. S. (2019). Analisis Komposisi Musik "Kuasa Tanah." Journal of Music Science, Technology, and Industry, 2 (1), 49-84. https://doi.org/doi: https://doi.org/10.31091/jomsti.v2i1

Rohmatullah, M. (2020). Musical Composition of Introverts and Ekstroverts' Extramusical Idea. Journal of Music Science, Technology, and Industry., 3 (2), 125-133. https://jurnal.isi-

dps.ac.id/index.php/jomsti/issue/view/54.

Rosar, W. H. (2002). Film Music-What's in a Name? The Journal of Film Music, 1 (1), 1-18. Retrieved from http://www.csulb.edu/ landerse/ifms/Edit orial.pdf

Sitompul, A. (2017). Metamorfosis Kupu-Kupu: Sebuah Komposisi Musik. Jurnal

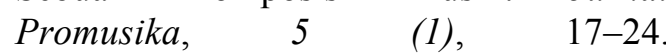
https://doi.org/https://doi.org/10.24821/pr omusika.v5i1

Stein, L. (1979). Structure and Style. The Study of Analysis of Musical Forms. Miami: Summy-Birchard Music.

Sterling, C. H. (2008). Military Communications: From Ancient Times to the 21st Century in Medieval Military Signaling (500-1500 CE). ABD-CLIO.

Stevenson, G. (1972). Discography: Scientific, Analytical, Historical, and Systematic. Urbana: University of Illnois.

Subana. (2011). Dasar-Dasar Penelitian Ilmiah. Bandung: Pustaka Setia.

Sugiyono. (2012). Metode Penelitian Kuantitatif Kualitatif dan $R \& D$. Bandung: Alfabeta.

Tan, S.-L. (2016). The Psychology of Film Music: Framing Intuition. Music and the Moving Image, 9 (2), 23-38. https://doi.org/https://doi.org/10.5406/mus imoviimag.9.2.23

Turnbull, S. (2012). War in Japan 1467-1615. Oxford: Osprey Publishing.

Walus, B. P. (2012). A New Modular Approach to the Composition of Film Music. Adelaide: University of Adelaide.

Werlé, X. D. (2014). The Music of World of Warcraft: Lore of Epic Music [University of California]. Retrieved from https://escholarship.org/uc/item/2xk8k2m $\mathrm{x}$ 